\title{
EFFORTS TO IMPROVE DISCIPLINE STUDENTS THROUGH CHARACTER STRENGTHENING IN SMA NEGERI 9 YOGYAKARTA
}

\author{
Jumadi \\ SMA Negeri 9 Yogyakarta \\ Email:drs.jumadi27@gmail.com
}

\begin{abstract}
This study aims to improve the discipline of students at SMA Negeri 9 Yogyakarta. The character of students at SMA Negeri 9 Yogyakarta is in a good category. If appropriately managed, this character has the potential to positively affect the discipline of students.

This research was conducted in SMA Negeri 9 Yogyakarta. This research was conducted in 2 cycles. The development of this Best Practice is focused on improving student discipline through Strengthening Character Education (PPK) in SMA Negeri 9 Yogyakarta with details of the number of male students at SMA Negeri 9 Yogyakarta is 213 people, equivalent to $37.50 \%$ and female students totaled 355 people. Or the equivalent of $62.50 \%$. The observation sheet in this research instrument will use a checklist.

Best practice activities have succeeded in improving student discipline by strengthening character education (PPK) at SMA Negeri 9 Yogyakarta. This is evidenced by an increase in students' average discipline developing optimally, namely from class X, XI, and XII. From the initial conditions, it is still low or has not developed optimally. In Cycle $\mathrm{I}$, there was an increase compared to the initial conditions before corrective action, namely with the criteria starting to develop, only class XI changed to class X and XI, and class XII developed as expected, in cycle II, action had an increase compared to cycle I, in cycle I all class X and XI began to develop. Class XII developed according to expectations, turning into class X developing according to expectations, and class XI and XII developing very well. In contrast, the assessment criteria began to develop and had not developed yet.
\end{abstract}

Keywords: Discipline, Character Strengthening, SMA Negeri 9 Yogyakarta

\section{UPAYA MENINGKATKAN KEDISIPLINAN PESERTA DIDIK MELALUI PENGUATAN KARAKTER DI SMA NEGERI 9 YOGYAKARTA}

\begin{abstract}
Abstrak
Penelitian ini bertujuan untuk meningkatkan kedisiplinan peserta didik di SMA Negeri 9 Yogyakarta. Karakter siswa di SMA Negeri 9 Yogyakarta tergolong dalam kategori baik. Karakter tersebut jika dikelola dengan baik sangat berotensi menimbulkan efek positif yang kedisilinan peserta didik.

Penelitian ini merupakan yang dilaksanakan di SMA Negeri 9 Yogyakarta. Penelitian ini dilaksanakan dalam 2 siklus. Pengembangan pada Best Practice ini difokuskan pada upaya meningkatkan kedisiplinan peserta didik melalui Penguatan Pendidikan Karakter (PPK) di SMA Negeri 9 Yogyakarta dengan rincian jumlah siswa laki-laki pada SMA Negeri 9 Yogyakarta adalah 213 orang atau setara dengan $37.50 \%$ dan siswa perempuan berjumlah 355 orang atau setara dengan $62.50 \%$. Lembar observasi dalam instrumen penelitian ini akan menggunakan chek list.
\end{abstract}


Kegiatan best practice berhasil meningkatkan kedisiplinan peserta didik melalui penguatan pendidikan karakter (PPK) di SMA Negeri 9 Yogyakarta dibuktikan dengan adanya peningkatan rata-rata kedisiplinan peserta didik berkembang secara optimal yaitu dari kelas X, XI dan XII. Dari kondisi awal masih rendah atau belum berkembang secara optimal. Pada Siklus I mengalami peningkatan dibandingkan dengan kondisi awal sebelum tindakan perbaikan yaitu dengan kriteria mulai berkembang tadinya hanya kelas XI berubah menjadi kelas X dan XI dan kelas XII berkembang sesuai harapan, pada tindakan siklus II mengalami peningkatan dibandingkan siklus I, pada siklus I semua kelas X dan XI mulai berkembang dan kelas XII berkembang sesuai harapan berubah menjadi kelas X berkembang sesuai harapan dan kelas XI dan XII berkembang sangat Baik, sedangkan untuk kriteria penilaian mulai berkembang dan belum berkembang sudah tidak ada lagi.

Kata Kunci: Kedisiplinan, Penguatan Karakter, SMA Negeri 9 Yogyakarta

\section{PENDAHULUAN}

Kedisiplinan merupakan serangkaian sikap yang menunjukkan nilai-nilai ketaatan, kepatuhan, keteraturan, dan ketertiban. Dalam dunia pendidikan kedisiplinan merupakan proses yang sangat diperlukan untuk menjaga agar proses belajar mengajar dapat berjalan dengan baik dan lancar dan bisa menciptakan pribadi yang kuat bagi peserta didik. Dengan ditanamkan kedisiplinan kepada peserta didik dengan baik diharapkan dapat mewujudkan pendidikan karakter sebagaimana yang tertuang dalam fungsi dan tujuan pendidikan nasional, yaitu "Pendidikan nasional berfungsi mengembangkan dan membentuk watak serta peradaban bangsa yang bermartabat dalam rangka mencerdaskan kehidupan bangsa, bertujuan untuk berkembangnya potensi peserta didik agar menjadi manusia yang beriman dan bertakwa kepada Tuhan Yang Maha Esa, berakhlak mulia, sehat, berilmu, cakap, kreatif, mandiri, dan menjadi warga negara yang demokratis serta bertanggung jawab”.

Sehubungan dengan itu, penyelenggaraan pendidikan nasional terutama pendidikan menengah pertama dapat dikatakan sudah berada pada jalur yang tepat, on the track, karena telah mendidikkan karakter sekaligus membentuk intelektualitas berupa kompetensi. Meskipun demikian, dalam membentuk kedisiplinan peserta didik melalui pendidikan karakter belum berimbang akibat berbagai faktor. Usaha penyeimbangan pendidikan karakter dengan pembentukan kompetensi senantiasa harus dilakukan. Demi kepentingan masa depan bangsa Indonesia, bahkan sejak sekarang perlu dilakukan pemusatan (centering) pendidikan karakter dalam penyelenggaraan pendidikan nasional Indonesia.

Dengan adanya upaya meningkatkan kedisiplinan peserta didik melalui Penguatan Pendidikan Karakter (PPK) diharapkan dapat melahirkan sekolah rintisan yang mampu melaksanakan pembentukan karakter secara kontekstual sesuai dengan potensi lingkungan setempat.

Atas dasar itu, SMA Negeri 9 Yogyakarta berupaya meningkatkan kediisiplinan peserta didik melalui Penguatan Pendidikan Karakter (PPK), bukan sekedar mengajarkan mana yang benar dan mana yang salah, lebih dari itu, menanamkan kebiasaan (babituation) tentang hal mana yang baik sehingga peserta didik menjadi paham (kognitif) tentang mana yang benar dan salah, mampu merasakan (afektif) nilai yang baik dan biasa melakukannya (psikomotor). Dengan kata lain, pendidikan karakter yang baik harus melibatkan bukan saja 
aspek "pengetahuan yang baik (moral knowing), akan tetapi juga "merasakan dengan baik atau loving good (moral feeling), dan perilaku yang baik (moral action).

Dari beberapa masalah yang berhasil diidentifikasi oleh penulis. Penulis memfokusikan penelitian best practice ini untuk meningkatkan kedisiplinan peserta didik melalui Penguatan Pendidikan Karakter (PPK) di SMA Negeri 9 Yogyakarta . Untuk mencapai tujuan tersebut, penulis merumuskan beberapa masalah, yaitu 1) Bagaimana meningkatkan kedisiplinan peserta didik melalui Penguatan Pendidikan Karakter (PPK)?; 2) Bagaimana merumuskan nilai-nilai utama karakter oleh sekolah sejalan dengan semangat globalisasi, mengadopsi nilai-nilai keutamaan lokal dan sejalan dengan perkembangan anak?; 3) Bagaimana motivasi anak didik terhadap kegiatan pembelajaran?; dan 4) Bagaimana mengembangkan potensi-potensi intelektual dan karakter peserta didik?

Apabila program Best Practice Upaya Meningkatkan Kedisiplinan Peserta Didik Melalui Penguatan Pendidikan Karakter (PPK) di SMA Negeri 9 Yogyakarta ini berhasil diharapkan memberikan manfaat yang pertama untuk meningkatkan pendidikan karakter peserta didik dalam menghadapi kompetensi abad 21, yaitu: berpikir kritis, kreativitas, komunikasi, dan kolaborasi; kedua, memberikan pembelajaran dilakukan terintegrasi di sekolah dan di luar sekolah dengan pengawasan guru; ketiga, revitalisasi peran Kepala Sekolah sebagai manager dan Guru sebagai inspirator Penguatan Pendidikan Karakter; dan keermpat, Revitalisasi Komite Sekolah sebagai badan gotong royong sekolah dan partisipasi masyarakat.

\section{Kedisiplinan}

Kata disiplin berasal dari bahasa latin yaitu Discere yang berarti belajar. Berdasarkan kata tersebut, muncullah kata Disciplina yang mempunyai arti pengajaran atau pelatihan. Dalam bahasa Inggris disiplin yaitu Disciple yang memiliki arti pengikut atau murid.

Pengertian disiplin menurut Depdiknas adalah suatu sikap konsisten dalam melakukan sesuatu. Menurut pandangan ini disiplin sebagai suatu konsisten dalam melakukan sesuatu. Sedangkan menurut Hougton disiplin adalah pola perilaku yang diharapkan akan menghasilkan karakter tertentu, khususnya menghasilkan peningkatan moral dan mental yang lebih teratur. Disiplin adalah kontrol diperoleh dengan menegakkan kepatuhan atau perintah. Sementara itu Suharsimi Arikunto (1980: 114), Disiplin adalah kepatuhan seseorang dalam mengikuti peraturan atau tata tertib karena didorong oleh adanya kesadaran yang ada pada kata hatinya tanpa adanya paksaan dari pihak luar.

Dari ketiga pendapat di atas dapat disimpulkan bahwa disiplin merupakan sebuah rasa taat dan patuh kepada nilai yang dipercaya yang menjadi tanggung jawabnya, patuh terhadap aturan atau tunduk pada pengawasan dan pengendalian.

\section{Peserta Didik}

Secara etimologi peserta didik adalah anak didik yang mendapat pengajaran ilmu. Secara terminologi peserta didik adalah anak didik atau individu yang mengalami perubahan, perkembangan sehingga masih memerlukan bimbingan dan arahan dalam membentuk kepribadian serta sebagai bagian dari struktural proses pendidikan.

Secara bahasa peserta didik adalah orang yang sedang berada pada fase pertumbuhan dan perkembangan baik secara fisik maupun psikis, pertumbuhan dan perkembangan merupakan ciri dari seseorang peserta didik yang perlu bimbingan dari seorang pendidik. Pertumbuhan yang menyangkut fisik, perkembangan menyangkut psikis. 
Menurut pasal 1 ayat 4 UU RI No. 20 Tahun 2003 tentang Sistem Pendidikan Nasional, peserta didik adalah anggota masyarakat yang berusaha mengembangkan dirinya melalui proses pendidikan pada jalur jenjang dan jenis.

\section{Penguatan Pendidikan Karakter}

Pelaksana Penguatan Pendidikan Karakter yang diselenggarakan oleh Direktorat Jenderal Pendidikan Dasar dan Menengah pada tanggal 14 September 2016 Kemdikbud menemukan bahwa sebagian besar sekolah yang diundang sudah menerapkan pendidikan karakter melalui pembiasaan dengan kegiatan penumbuhan dan pembudayaan nilai-nilai karakter yaitu yang disepakati oleh masing-masing sekolah. Kerja sama dan komitmen dari kepala sekolah, guru, dan orangtua umumnya menjadi menjadi faktor kunci keberhasilan pelaksanaan pendidikan karakter di masing-masing sekolah tersebut.

Penerapan penguatan pendidikan karakter akan berjalan dengan baik apabila kepala sekolah sebagai pemimpin mampu menjadi pemimpin yang kredibel dan visioner. Kredibel berarti Kepala Sekolah memiliki sosok berintegritas, mampu menjadi manajer yang fokusnya adalah peningkatan kualitas pembelajaran melalui pembentukan karakter. Visioner berarti kepala sekolah memiliki visi jauh ke depan tentang "branding” sekolah yang akan ia bangun. Kemampuan manajerial kepala sekolah untuk menggali potensi lingkungan sebagai sumber belajar dan mengembangkan kerja sama dengan berbagai pemangku kepentingan dalam ekosistem pendidikan yang ada untuk mendukung program sekolah sangat diperlukan.

\section{METODE}

Penelitian best practice ini dilaksanakan di SMA Negeri 9 Yogyakarta. Penelitian ini dilaksanakan pada bulan Oktober 2018 Semester I (Ganjil) Tahun Ajaran 2018/2019 dengan 2 siklus. Siklus I dilaksanakan pada Selasa (9/10/2018) sampai dengan Selasa (06/11/2018). Siklus II dilaksanakan pada Rabu (16/1/2019) sampai dengan Rabu (06/3/2019)

Bidang Pengembangan pada Best Practice ini akan difokuskan pada upaya meningkatkan kedisiplinan peserta didik melalui Penguatan Pendidikan Karakter (PPK) di SMA Negeri 9 Yogyakarta dengan rincian jumlah siswa laki-laki pada SMA Negeri 9 Yogyakarta adalah 213 orang atau setara dengan $37.50 \%$ dan siswa perempuan berjumlah 355 orang atau setara dengan $62.50 \%$.

\section{Prosedur Penelitian}

Penelitian Best Practice ini akan dilaksanakan dengan 2 siklus yang setiap siklusnya terdiri dari 4 langkah diantaranya yaitu perencanaan, pelaksanaan, observasi/ pengamatan dan refleksi.

\section{Siklus I}

Tahap Perencanaan. Tindakan yang akan dilaksanakan dalam rancangan siklus I, yaitu peneliti merencanakan dalam bentuk skenario perbaikan kedisiplinan, dengan rincian kegiatan pada tabel 1. 
Tabel 1. Skenario Perbaikan Kedisiplinan pada Siklus I

\begin{tabular}{|c|c|}
\hline No & Uraian \\
\hline 1 & $\begin{array}{l}\text { Sebelum masuk diruang kelas siswa terlebih dahulu menyanyikan lagu Indonesia } \\
\text { Raya dan lagu wajib lainnya }\end{array}$ \\
\hline 2 & $\begin{array}{l}\text { Sebelum pembelajaran di mulai atau setiap hari seluruh siswa diminta membaca } \\
\text { surat-surat pendek dari kitab suci, melakukan refleksi (masa hening) selama } 15 \text { s.d } \\
20 \text { menit }\end{array}$ \\
\hline 3 & $\begin{array}{l}\text { Di hari Jum'at sebelum pembelajaran dimulai dilakukan kegiatan muhadarah } \\
\text { (berkumpul dihalaman sekolah) selama } 35 \text { menit. Kegiatan itu berupa ceramah } \\
\text { keagaamaan diisi oleh Kepala Sekolah, guru, peserta didik, ataupun dari pihak luar }\end{array}$ \\
\hline 4 & $\begin{array}{l}\text { Siswa dibiasakan shalat dzuhur dan dhuha berjamah yang dilakukan di Mushalla } \mathrm{Al} \\
\text { Ilmu SMA Negeri } 9 \text { Yogyakarta }\end{array}$ \\
\hline 5 & $\begin{array}{l}\text { Setiap hari Jumat semua guru, TU dan semua karyawan melaksanakan Majlis } \\
\text { Taklim bersama }\end{array}$ \\
\hline 6 & Pelaksanaan pesantren kilat pada bulan ramadhan dan buka puasa bersama \\
\hline 7 & $\begin{array}{l}\text { Pelaksanaan 'Idul Qurban, merayakan hari-hari besar keagamaan; serta guru piket } \\
\text { menyambut kedatangan siswa pagi hari di gerbang sekolah sambil bersalaman }\end{array}$ \\
\hline 8 & $\begin{array}{l}\text { Melakukan kegiatan istighosah bersama khususnya kelas XII dan orang tua siswa, } \\
\text { sebelum menghadapi Ujian }\end{array}$ \\
\hline
\end{tabular}

\section{Langkah-langkah Perbaikan}

Langkah-langkah perbaikan pada siklus I secara terperinci adalah 1) hadir 10 menit lebih awal sebelum mata pelajaran pertama kali di mulai di pagi hari; 2) mematuhi penggunaan atribut seragam sekolah seperti misalnya tidak menggunakan sepatu selain yang berwarna hitam; 3) mengikuti upacara bendera dengan khidmat; 4) menggunakan seragam sekolah yang bersih dan tidak ketat; dan 5) menghormati guru, kepala sekolah, staf sekolah serta siswa lainnya di sekolah

Tahap Pelaksanaan. Dalam pelaksanaan penelitian ini, peneliti menentukan penilaian, dengan rincian sebagai berikut:

Tugas 1, yaitu 1) Mempelajari panduan kedisiplinan peserta didik dan PPK; 2) Mempelajari karakteristik peserta didik; dan 3) Merencanakan pembuatan laporan Best Practice Upaya Meningkatkan Kedisiplinan Peserta Didik Melalui Penguatan Pendidikan Karakter (PPK) di SMA Negeri 9 Yogyakarta. Prosedur kegiatan pengembangan pada siklus I dapat dicermati pada Tabel 2.

Tabel 2. Prosedur Kegiatan Pengembangan pada Siklus I

\begin{tabular}{|c|l|}
\hline No & \multicolumn{1}{|c|}{ Uraian } \\
\hline 1 & $\begin{array}{l}\text { Sebelum masuk diruang kelas siswa terlebih dahulu menyanyikan lagu Indonesia } \\
\text { Raya dan lagu wajib lainnya }\end{array}$ \\
\hline 2 & $\begin{array}{l}\text { Sebelum pembelajaran di mulai atau setiap hari seluruh siswa diminta membaca } \\
\text { surat-surat pendek dari kitab suci, melakukan refleksi (masa hening) selama 15 s.d } 20 \\
\text { menit }\end{array}$ \\
\hline
\end{tabular}




\begin{tabular}{|c|l|}
\hline No & \multicolumn{1}{|c|}{ Uraian } \\
\hline 3 & $\begin{array}{l}\text { Di hari Jum'at sebelum pembelajaran dimulai dilakukan kegiatan muhadarah } \\
\text { (berkumpul dihalaman sekolah) selama 35 menit. Kegiatan itu berupa ceramah } \\
\text { keagaamaan diisi oleh Kepala Sekolah, guru, peserta didik, ataupun dari pihak luar }\end{array}$ \\
\hline 4 & $\begin{array}{l}\text { Siswa dibiasakan shalat dzuhur dan dhuha berjamah yang dilakukan di Mushalla Al } \\
\text { Ilmu SMA Negeri 9 Yogyakarta }\end{array}$ \\
\hline 5 & $\begin{array}{l}\text { Setiap hari Jumat semua guru, TU dan semua karyawan melaksanakan Majlis Taklim } \\
\text { bersama }\end{array}$ \\
\hline 6 & Pelaksanaan pesantren kilat pada bulan ramadhan dan buka puasa bersama \\
\hline 7 & $\begin{array}{l}\text { Pelaksanaan 'Idul Qurban, merayakan hari-hari besar keagamaan; serta guru piket } \\
\text { menyambut kedatangan siswa pagi hari di gerbang sekolah sambil bersalaman }\end{array}$ \\
\hline 8 & $\begin{array}{l}\text { Melakukan kegiatan istighosa bersama khususnya kelas XII dan orang tua siswa, } \\
\text { sebelum menghadapi Ujian }\end{array}$ \\
\hline
\end{tabular}

Secara umum prosedur pengembangan Upaya Meningkatkan Kedisiplinan Peserta Didik Melalui Penguatan Pendidikan Karakter (PPK) di SMA Negeri 9 Yogyakarta merupakan kegiatan anak yang sering melibatkan kemampuan anak dalam melakukan suatu kegiatan yang awalnya anak tidak mengetahui dengan menggunakan berbagai cara kegiatan dan media yang menarik serta mudah dipahami oleh anak dalam situasi yang menyenangkan dan motivasi pendidik/guru dalam memfasilitasi berbagai bahan, media, sarana dan teknik pelaksanaan untuk tujuan perbaikan pengembangan agar berhasil optimal.

Tahap Observasi/Pengamatan. Kegiatan observasi ini dilakukan bersamaan dengan pelaksanaan kedisiplinan di SMA Negeri 9 Yogyakarta. Peneliti bertindak secara langsung sebagai kepala sekolah dalam melaksanakan kegiatan pembelajaran dan mengamati seluruh kegiatan yang dilakukan oleh guru dan anak dalam kegiatan belajar mengajar. Observasi yang dilakukan dalam penelitian Best Practice tentang Upaya Meningkatkan Kedisiplinan Peserta Didik Melalui Penguatan Pendidikan Karakter (PPK) di SMA Negeri 9 Yogyakarta adalah observasi sistematis artinya dilakukan oleh peneliti dengan menggunakan instrumen penelitian berupa Lembar Observasi Kedisiplinan Peserta Didik Melalui Penguatan Pendidikan Karakter (PPK) di SMA Negeri 9 Yogyakarta.

Tahap Refleksi. Kegiatan yang dilaksanakan pada tahap ini adalah mengevaluasi kelebihan dan kelemahan yang ada dalam penerapan kedisiplinan peserta didik melalui Penguatan Pendidikan Karakter (PPK). Refleksi pada siklus pertama ini sangat berfungsi untuk merencanakan siklus yang ke dua.

\section{Siklus II}

Tahap Perencanaan. Tindakan yang akan dilaksanakan dalam rancangan siklus II, yaitu peneliti merencanakan dalam bentuk skenario perbaikan kedisiplinan, dengan rincian kegiatan dapat dicermati pada tabel 3.

Tabel 3. Skenario Perbaikan Kedisiplinan pada Siklus II

\begin{tabular}{|c|l|}
\hline No & \multicolumn{1}{|c|}{ Uraian } \\
\hline 1 & $\begin{array}{l}\text { Sebelum masuk diruang kelas siswa terlebih dahulu berbaris di depan kelas dan } \\
\text { menyanyikan lagu Indonesia Raya dan lagu wajib lainnya }\end{array}$ \\
\hline
\end{tabular}




\begin{tabular}{|c|c|}
\hline No & Uraian \\
\hline 2 & $\begin{array}{l}\text { Sebelum pembelajaran di mulai atau setiap hari seluruh siswa diminta membaca } \\
\text { surat-surat pendek dari kitab suci, melakukan refleksi (masa hening) selama } 15 \text { s.d } 20 \\
\text { menit dilanjutkan dengan membaca Buku/Novel sebagai bentuk kegiatan literasi } \\
\text { sekolah }\end{array}$ \\
\hline 3 & $\begin{array}{l}\text { Di hari Jum'at sebelum pembelajaran dimulai dilakukan kegiatan muhadarah } \\
\text { (berkumpul dihalaman sekolah) selama } 35 \text { menit. Kegiatan itu berupa ceramah } \\
\text { keagaamaan diisi oleh Kepala Sekolah, guru, peserta didik, ataupun dari pihak luar }\end{array}$ \\
\hline 4 & $\begin{array}{l}\text { Siswa dibiasakan shalat dzuhur dan dhuha berjamah yang dilakukan di Mushalla Al } \\
\text { Ilmu SMA Negeri } 9 \text { Yogyakarta }\end{array}$ \\
\hline 5 & $\begin{array}{l}\text { Setiap hari Jumat semua guru, TU dan semua karyawan melaksanakan Majlis Taklim } \\
\text { bersama }\end{array}$ \\
\hline 6 & Pelaksanaan pesantren kilat pada bulan ramadhan dan buka puasa bersama \\
\hline 7 & $\begin{array}{l}\text { Pelaksanaan 'Idul Qurban, merayakan hari-hari besar keagamaan; serta guru piket } \\
\text { menyambut kedatangan siswa pagi hari di gerbang sekolah sambil bersalaman }\end{array}$ \\
\hline 8 & $\begin{array}{l}\text { Melakukan kegiatan istighosa bersama khususnya kelas XII dan orang tua siswa, } \\
\text { sebelum menghadapi Ujian }\end{array}$ \\
\hline
\end{tabular}

Langkah-langkah perbaikan pada siklus II secara terperinci adalah sebagai berikut 1) Peserta didik bersalaman dengan guru dengan mengucapkan salam ketika sampai di pintu gerbang; 2) Hadir 10 menit lebih awal sebelum mata pelajaran pertama kali di mulai di pagi hari; 3); Mematuhi penggunaan atribut seragam sekolah seperti misalnya tidak menggunakan sepatu selain yang berwarna hitam; 4) Mengikuti upacara bendera dengan khidmat; 5) Menggunakan seragam sekolah yang bersih dan tidak ketat; 6) Baju pada seragam sekolah selalu diperhatikan agar berada di dalam sehingga ikat pinggang terlihat; dan 7) Menghormati guru, kepala sekolah, staf sekolah serta siswa lainnya di sekolah.

Tahap Pelaksanaan. Tahap pelaksanaan pada siklus II adalah dengan prosedur kegiatan pengembangan dapat dicermati pada tabel 4 .

Tabel 4. Prosedur Kegiatan Pengembangan pada Siklus II

\begin{tabular}{|c|l|}
\hline No & \multicolumn{1}{|c|}{ Uraian } \\
\hline 1 & $\begin{array}{l}\text { Sebelum masuk diruang kelas siswa terlebih dahulu berbaris di depan kelas dan } \\
\text { menyanyikan lagu Indonesia Raya dan lagu wajib lainnya }\end{array}$ \\
\hline 2 & $\begin{array}{l}\text { Sebelum pembelajaran di mulai atau setiap hari seluruh siswa diminta membaca } \\
\text { surat-surat pendek dari kitab suci, melakukan refleksi (masa hening) selama 15 s.d } \\
20 \text { menit dilanjutkan dengan membaca Buku/Novel sebagai bentuk kegiatan } \\
\text { literasi sekolah }\end{array}$ \\
\hline 3 & $\begin{array}{l}\text { Di hari Jum'at sebelum pembelajaran dimulai dilakukan kegiatan muhadarah } \\
\text { (berkumpul dihalaman sekolah) selama 35 menit. Kegiatan itu berupa ceramah } \\
\text { keagaamaan diisi oleh Kepala Sekolah, guru, peserta didik, ataupun dari pihak luar }\end{array}$ \\
\hline 4 & $\begin{array}{l}\text { Siswa dibiasakan shalat dzuhur dan dhuha berjamah yang dilakukan di Mushalla } \\
\text { Al Ilmu SMA Negeri 9 Yogyakarta }\end{array}$ \\
\hline
\end{tabular}




\begin{tabular}{|c|l|}
\hline No & \multicolumn{1}{|c|}{ Uraian } \\
\hline 5 & $\begin{array}{l}\text { Setiap hari Jumat semua guru, TU dan semua karyawan melaksanakan Majlis } \\
\text { Taklim bersama }\end{array}$ \\
\hline 6 & Pelaksanaan pesantren kilat pada bulan ramadhan dan buka puasa bersama \\
\hline 7 & $\begin{array}{l}\text { Pelaksanaan 'Idul Qurban, merayakan hari-hari besar keagamaan; serta guru piket } \\
\text { menyambut kedatangan siswa pagi hari di gerbang sekolah sambil bersalaman }\end{array}$ \\
\hline 8 & $\begin{array}{l}\text { Melakukan kegiatan istighosa bersama khususnya kelas XII dan orang tua siswa, } \\
\text { sebelum menghadapi Ujian }\end{array}$ \\
\hline
\end{tabular}

Tahap Observasi/Pengamatan. Tahap observasi pada siklus ke II yaitu mengobservasi proses dan hasil anak dalam kegiatan Upaya Meningkatkan Kedisiplinan Peserta Didik Melalui Penguatan Pendidikan Karakter (PPK). Adapun instrumen observasinya adalah sama dengan instrumen observasi pada penilaian siklus ke I.

Tahap Refleksi. Sama halnya dengan tahap refleksi siklus ke I yaitu pada tahap refleksi siklus ke II yaitu mengevaluasi kelebihan dan kekurangan yang terjadi pada tahap ke II, dan tahap ini menentukan perlu atau tidaknya perbaikan pada tahap selanjutnya. Jika pada refleksi siklus ke II perbaikan kedisiplinan masih belum berhasil maka diperlukan perbaikan kedisiplinan pada siklus berikutnya, tetapi jika hasil refleksi pada tahap ke II ini perbaikan kedisiplinannya sudah berhasil dan sesuai yang diharapkan maka tidak perlu untuk melakukan perbaikan kedisiplinan pada siklus berikutnya sehingga perbaikan kedisiplinan hanya 2 siklus.

\section{Instrumen Penelitian}

\section{Lembar Observasi}

Lembar observasi dalam instrumen penelitian ini akan menggunakan chek list. Menurut Wina Sanjaya (2011:93) bahwa daftar cek atau chek list merupakan pedoman observasi yang berisikan daftar dari semua aspek yang akan diobservasi, sehingga observer tinggal memberi tanda atau tidak adanya dengan tanda cek $(\sqrt{ })$ tentang aspek yang diobservasi.

\section{HASIL DAN PEMBAHASAN}

\section{Hasil Penelitian}

Upaya Meningkatkan Kedisiplinan Peserta Didik Melalui Penguatan Pendidikan Karakter (PPK) di SMA Negeri 9 Yogyakarta ini merupakan bentuk tahap-tahap pendekatan ilmiah dalam proses pembelajaran. Proses pembelajaran dimulai dengan kegiatan mengamati, mengumpulkan data, membuat hipotesis, menguji hipotesis, menarik simpulan, dan menyampaikan hasil penelitian. Fokus pembentukan karakter dalam metode pembelajaran ini adalah berpikir kritis dan logis dengan mempergunakan metode ilmiah yang teruji untuk memajukan ilmu.

Dalam pembuatan laporan best practice ini terdiri dari 2 siklus, dengan prosedur penelitian meliputi penyusunan rencana tindakan, pelaksanaan, pengamatan atau observasi dan refleksi yang masing-masing siklus akan dideskripsikan sebagai berikut:

\section{Kondisi Awal}

Peneliti melakukan observasi atau pengamatan ini bertujuan untuk meningkatkan kedisiplinan peserta didik melalui Penguatan Pendidikan Karakter (PPK) di SMA Negeri 9 
Yogyakarta. Hasil yang diperoleh pada kondisi awal sebelum tindakan akan dibandingkan dengan hasil setelah dilakukan tindakan Best Practice Upaya Meningkatkan Kedisiplinan Peserta Didik Melalui Penguatan Pendidikan Karakter (PPK). Hasil observasi sebelum diterapkan kedisiplinan peserta didik melalui Penguatan Pendidikan Karakter (PPK) masih banyak peserta didik yang belum sesuai mentaati peraturan sekolah yang ada.

Hal ini karena belum mempelajari kondisi awal dan memastikan taraf kesiapan sekolah dalam menyusun perencanaan dan pelaksanaan gerakan PPK di sekolah. Data tersebut dapat dilihat pada tabel 5. Berdasarkan data yang diperoleh, membuktikan bahwa kedisiplinan peserta didik pada SMA Negeri 9 Yogyakarta masih rendah atau belum berkembang secara optimal yaitu dari 3 kelas, kelas XII berkembang sesuai harapan atau sama dengan 33,3\%, kelas X mulai berkembang atau sama dengan 33,3\% dan Kelas X belum berkembang atau sama dengan 33,3\% dan dapat di gambarkan seperti grafik 1 .

Tabel 5

Lembar Observasi Kondisi Awal Peserta Didik SMA Negeri 9 Yogyakarta

\begin{tabular}{|c|c|c|c|c|c|c|c|c|c|c|c|c|c|c|c|c|c|c|}
\hline \multirow{3}{*}{ No } & \multirow{3}{*}{ Kelas } & \multicolumn{16}{|c|}{ KRITERIA } & \multirow{3}{*}{$\begin{array}{l}\text { Total } \\
\text { Skor }\end{array}$} \\
\hline & & \multicolumn{4}{|c|}{ Kesungguhan } & \multicolumn{4}{|c|}{$\begin{array}{c}\text { Santun } \\
\text { Menghargai }\end{array}$} & \multicolumn{4}{|c|}{$\begin{array}{c}\text { Kerjasama/ } \\
\text { Interaksi }\end{array}$} & \multicolumn{4}{|c|}{ Peduli } & \\
\hline & & 4 & 3 & 2 & 1 & 4 & 3 & 2 & 1 & 4 & 3 & 2 & 1 & 4 & & 2 & 1 & \\
\hline 1. & Kelas X & & & & $\sqrt{ }$ & & & & $\sqrt{ }$ & & & & $\sqrt{ }$ & & & & $\sqrt{ }$ & $4(\mathrm{BB})$ \\
\hline 2. & Kelas XI & & & $\sqrt{ }$ & & & & $\sqrt{ }$ & & & & $\sqrt{ }$ & & & & & $\sqrt{ }$ & 7 (MB) \\
\hline 3. & Kelas XII & & $\sqrt{ }$ & & & & $\sqrt{ }$ & & & & & $\sqrt{ }$ & & & & $\sqrt{ }$ & & $\begin{array}{c}10 \\
(\mathrm{BSH})\end{array}$ \\
\hline
\end{tabular}

Keterangan Penilaian Total Skor:

BSB : Total skor 11-13

BSH : Total skor 8-10

MB : Total skor 5-7

BB : Total skor 1-4

Tabel 6

Data Frekuensi dan Presentase Kondisi Awal Peserta Didik

\begin{tabular}{|c|l|c|c|}
\hline No & \multicolumn{1}{|c|}{ Kriteria Penilaian } & F & $\%$ \\
\hline 1 & Berkembang Sangat Baik & - & $0 \%$ \\
\hline 2 & Berkembang Sesuai Harapan & 1 & $33,3 \%$ \\
\hline 3 & Mulai Berkembang & 1 & $33,3 \%$ \\
\hline 4 & Belum Berkembang & 1 & $33,3 \%$ \\
\hline \multicolumn{2}{|l|}{ Jumlah } & 3 & $100 \%$ \\
\hline
\end{tabular}


Grafik 1

Data Frekuensi dan Persentase Kondisi Awal Anak

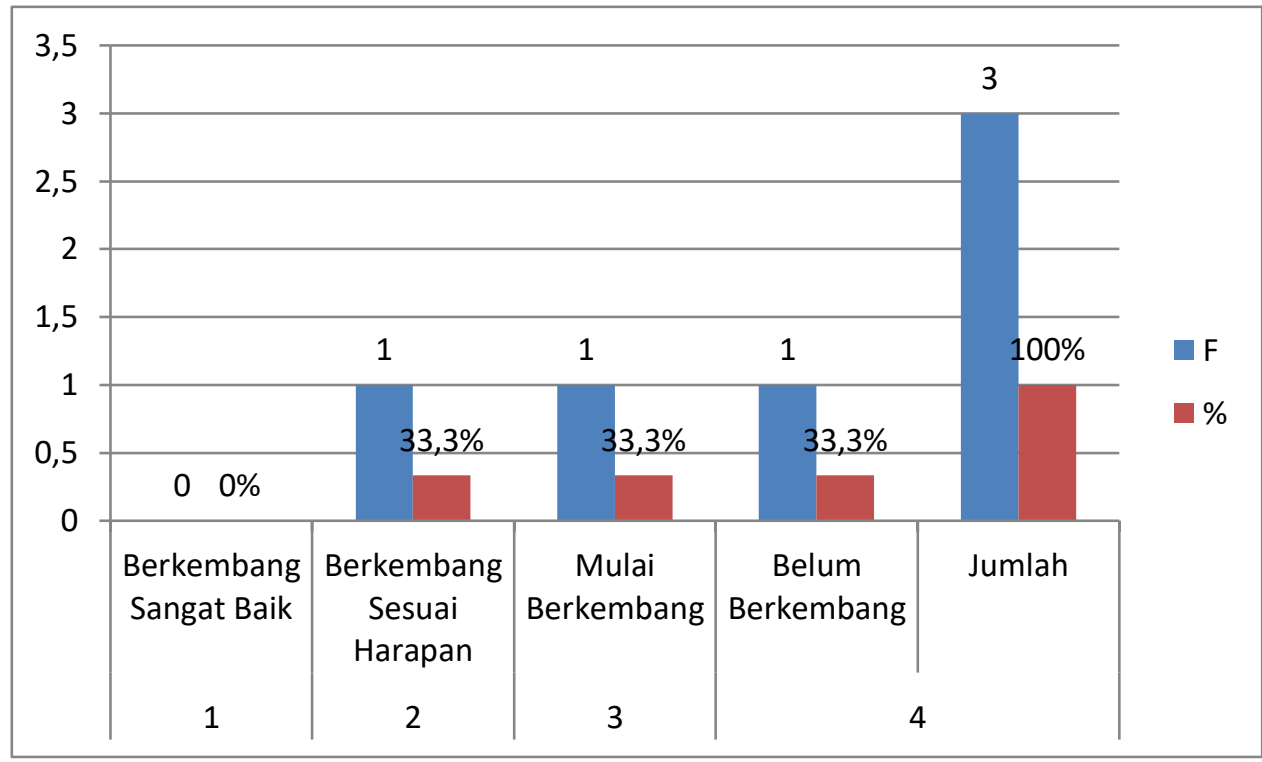

\section{Siklus I}

Pada tahap perencanaan, peneliti membuat laporan Best Practice Dalam Upaya Meningkatkan Kedisiplinan Peserta Didik Melalui Penguatan Pendidikan Karakter (PPK) di SMA Negeri 9 Yogyakarta. Kemudian peneliti juga membuat lembar observasi untuk mengamati aktifitas peserta didik.

Data yang diperoleh dari hasil observasi Siklus I dari hari Selasa, 09 Oktober 2018 s.d. Selasa, 06 Nopember 2018 dapat dicermati pada tabel 3.

Berdasarkan data pada tabel 5 dapat disimpulkan bahwa Upaya Meningkatkan Kedisiplinan Peserta Didik Melalui Penguatan Pendidikan Karakter (PPK) di SMA Negeri 9 Yogyakarta mengalami peningkatan dibandingkan dengan kondisi awal sebelum tindakan perbaikan yaitu dengan kriteria berkembang sesuai harapan yang tadinya hanya berjumlah 1 kelas berubah menjadi 2 kelas pada siklus I atau sama dengan $66,6 \%$, belum berkembang yang tadinya hanya 1 kelas meningkat mulai berkembang atau sama dengan 33,3\% seperti grafik 2 .

Tabel 7

Lembar Observasi Peserta Didik Siklus I

\begin{tabular}{|c|c|c|c|c|c|c|c|c|c|c|c|c|c|c|c|c|c|}
\hline \multirow{3}{*}{ No } & \multirow{3}{*}{ Kelas } & \multicolumn{15}{|c|}{ KRITERIA } & \multirow{3}{*}{$\begin{array}{l}\text { Total } \\
\text { Skor }\end{array}$} \\
\hline & & \multicolumn{4}{|c|}{ Kesungguhan } & \multicolumn{4}{|c|}{$\begin{array}{c}\text { Santun } \\
\text { Menghargai }\end{array}$} & \multicolumn{4}{|c|}{$\begin{array}{c}\text { Kerjasama/ } \\
\text { Interaksi }\end{array}$} & \multicolumn{3}{|c|}{ Peduli } & \\
\hline & & 4 & 3 & 2 & 1 & 4 & 3 & 2 & 1 & 4 & 3 & 2 & 1 & 4 & & 2 & \\
\hline 1. & Kelas X & & & $\sqrt{ }$ & & & & $\sqrt{ }$ & & & & & $\sqrt{ }$ & & & $\sqrt{ }$ & $\begin{array}{c}7 \\
(\mathrm{MB})\end{array}$ \\
\hline 2. & Kelas XI & & & $\sqrt{ }$ & & & & $\sqrt{ }$ & & & & $\sqrt{ }$ & & & & $\sqrt{ }$ & $\begin{array}{c}8 \\
(\mathrm{BSH})\end{array}$ \\
\hline 3. & Kelas XII & & $\sqrt{ }$ & & & & $\sqrt{ }$ & & & & & $\sqrt{ }$ & & & & $\sqrt{ }$ & $\begin{array}{c}10 \\
(\mathrm{BSH})\end{array}$ \\
\hline
\end{tabular}


Keterangan Penilaian Total Skor:

BSB : Total skor 11-13

BSH : Total skor 8-10

MB : Total skor 5-7

BB : Total skor 1-4

Tabel 8

Data Frekuensi dan Presentase Kondisi Awal Peserta Didik

\begin{tabular}{|c|l|c|c|}
\hline No & \multicolumn{1}{|c|}{ Kriteria Penilaian } & F & $\%$ \\
\hline 1 & Berkembang Sangat Baik & - & $0 \%$ \\
\hline 2 & Berkembang Sesuai Harapan & 2 & $66,6 \%$ \\
\hline 3 & Mulai Berkembang & 1 & $33,3 \%$ \\
\hline 4 & Belum Berkembang & - & $0 \%$ \\
\hline \multicolumn{2}{|l|}{ Jumlah } & 3 & $100 \%$ \\
\hline
\end{tabular}

Grafik 2

Data Frekuensi dan Presentase Peserta Didik Siklus I

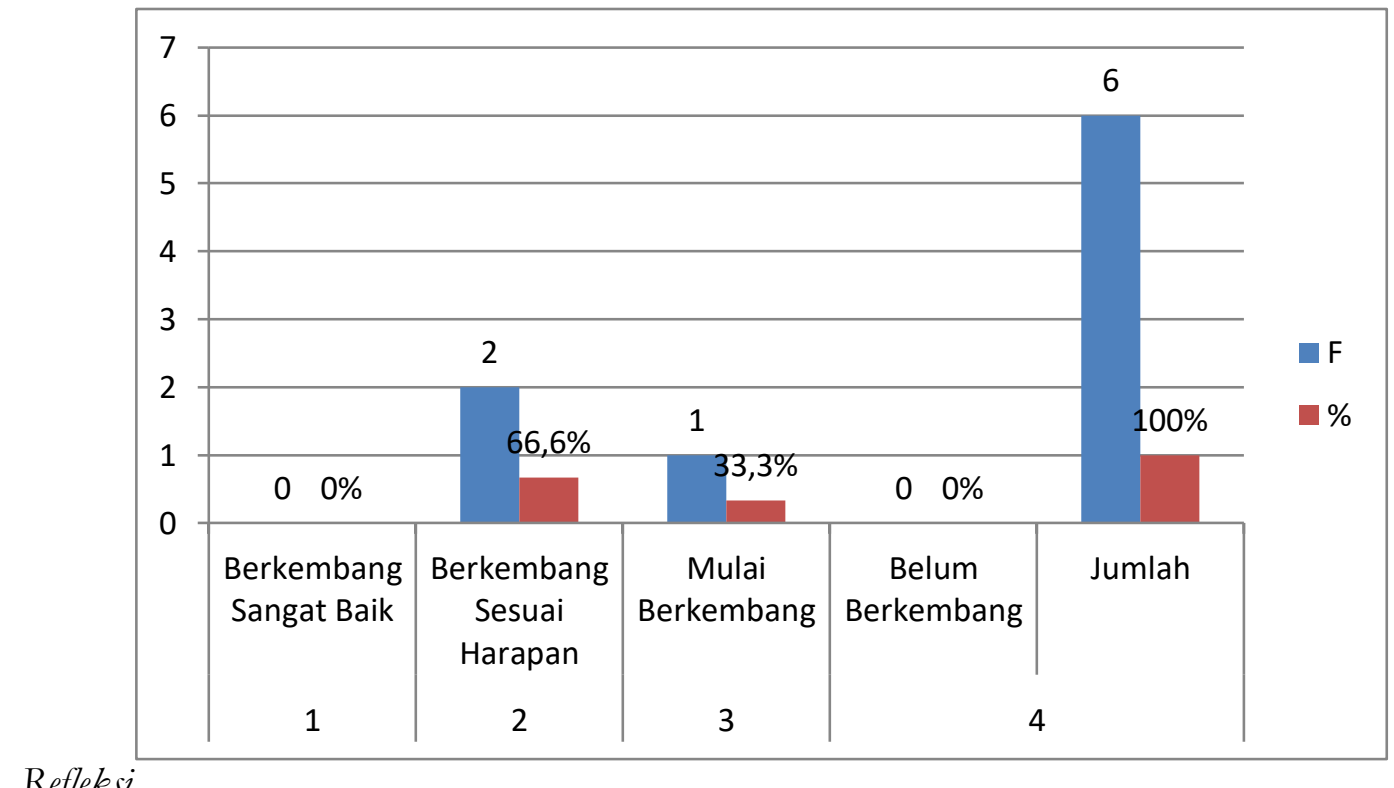

Refleksi

Pada tahap refleksi ini, peneliti melakukan perbandingan dengan melihat tabel observasi sebelum dilakakukan tindakan dan setelah pelaksanaan siklus I. Berdasarkan permasalahan yang muncul pada siklus I maka peneliti melakukan diskusi rekan guru-guru untuk mencari solusi dari permasalahn tersebut diantaranya yaitu:

1) Meningkatkan kedisiplinan peserta didik melalui Penguatan Pendidikan Karakter (PPK)

2) Merumusan nilai-nilai utama karakter oleh sekolah sejalan dengan semangat globalisasi, mengadopsi nilai-nilai keutamaan lokal dan sejalan dengan perkembangan anak.

3) Motivasi anak didik terhadap kegiatan pembelajaran

4) Mengembangkan potensi-potensi intelektual dan karakter peserta didik 


\section{Siklus II}

Pada tahap Perencanaan, peneliti membuat laporan Best Practice dalam upaya meningkatkan kedisiplinan peserta didik melalui Penguatan Pendidikan Karakter (PPK) di SMA Negeri 9 Yogyakarta. Kemudian peneliti juga membuat lembar observasi untuk mengamati aktifitas peserta didik.

Data yang diperoleh dari hasil observasi Siklus II dari hari Rabu, 16 Januari 2019 Rabu, 06 Maret 2019 dapat dicermati pada tabel 9.

Tabel 9

Lembar Observasi Peserta Didik Siklus II

\begin{tabular}{|c|c|c|c|c|c|c|c|c|c|c|c|c|c|c|c|c|c|c|}
\hline \multirow{3}{*}{ No } & \multirow{3}{*}{ Kelas } & \multicolumn{16}{|c|}{ KRITERIA } & \multirow{3}{*}{$\begin{array}{l}\text { Total } \\
\text { Skor }\end{array}$} \\
\hline & & \multicolumn{4}{|c|}{ Kesungguhan } & \multicolumn{4}{|c|}{$\begin{array}{c}\text { Santun } \\
\text { Menghargai }\end{array}$} & \multicolumn{4}{|c|}{$\begin{array}{c}\text { Kerjasama/ } \\
\text { Interaksi }\end{array}$} & \multicolumn{4}{|c|}{ Peduli } & \\
\hline & & 4 & 3 & 2 & 1 & 4 & 3 & 2 & 1 & 4 & 3 & 2 & 1 & 4 & 3 & 2 & 1 & \\
\hline 1. & Kelas X & & $\sqrt{ }$ & & & & & $\sqrt{ }$ & & & & $\sqrt{ }$ & & & $\sqrt{ }$ & & & $\begin{array}{c}10 \\
(\mathrm{BSH})\end{array}$ \\
\hline 2. & Kelas XI & & $\sqrt{ }$ & & & & $\sqrt{ }$ & & & & & $\sqrt{ }$ & & & & $\sqrt{ }$ & & $\begin{array}{c}10 \\
(\mathrm{BSH})\end{array}$ \\
\hline 3. & Kelas XII & $\sqrt{ }$ & & & & & $\sqrt{ }$ & & & & $\sqrt{ }$ & & & & $\sqrt{ }$ & & & $\begin{array}{c}13 \\
\text { (BSB) }\end{array}$ \\
\hline
\end{tabular}

Keterangan Penilaian Total Skor:

BSB : Total skor 11-13

BSH : Total skor 8-10

MB : Total skor 5-7

BB : Total skor 1-4

Tabel 10

Data Frekuensi dan Presentase Kondisi Awal Peserta Didik

\begin{tabular}{|c|l|c|c|}
\hline No & \multicolumn{1}{|c|}{ Kriteria Penilaian } & F & $\%$ \\
\hline 1 & Berkembang Sangat Baik & 1 & $33,3 \%$ \\
\hline 2 & Berkembang Sesuai Harapan & 2 & $66,6 \%$ \\
\hline 3 & Mulai Berkembang & - & $0 \%$ \\
\hline 4 & Belum Berkembang & - & $0 \%$ \\
\hline \multicolumn{2}{|l|}{ Jumlah } & 3 & $100 \%$ \\
\hline
\end{tabular}

Berdasarkan data pada tabel 10 dapat disimpulkan bahwa Upaya Meningkatkan Kedisiplinan Peserta Didik Melalui Penguatan Pendidikan Karakter (PPK) di SMA Negeri 9 Yogyakarta mengalami peningkatan dibandingkan dengan kondisi siklus I sebelum tindakan perbaikan yaitu dengan kriteria Berkembang Sangat Baik yang tadinya hanya berjumlah 0 kelas berubah menjadi 1 kelas pada siklus II dan mulai berkembang yang tadinya 1 kelas meninkat menjadi 
Berkembang Sesuai Harapan menjadi 2 kelas atau 66,6\%, sedangkan mulai berkembang dan belum berkembang sudah tidak ada lagi, seperti grafik 3 .

Berdasarkan hasil observasi dari kondisi awal, siklus I dan siklus II maka hasil tersebut dapat direkapitulasi dalam bentuk tabel 7. Dilihat dari tabel 7 bahwa Upaya Meningkatkan Kedisiplinan Peserta Didik Melalui Penguatan Pendidikan Karakter (PPK) di SMA Negeri 9 Yogyakarta dari mulai kondisi awal, siklus I dan siklus II mengalami peningkatan dan berkembang secara optimal serta sudah mencapai kriteria yang diharapkan, seperti pada grafik 4.

Grafik 3

Data Frekuensi dan Presentase Peserta Didik Siklus II

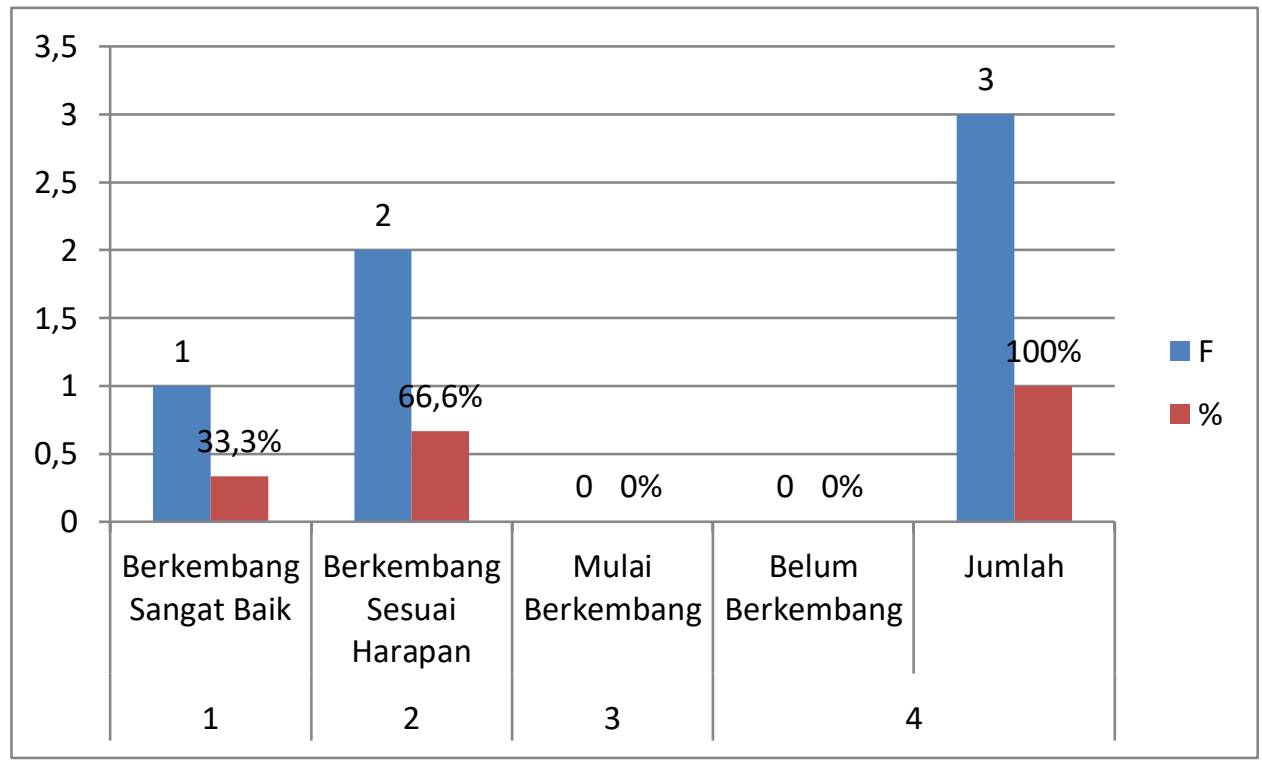

Tabel 11

Hasil Rekapitulasi Keberhasilan Anak Dari Kondisi Awal, Siklus I, dan Siklus II

\begin{tabular}{|c|c|c|c|c|c|c|c|}
\hline $\mathrm{N}$ & \multirow[t]{2}{*}{ Kriteria Penilaian } & \multicolumn{2}{|c|}{$\begin{array}{c}\text { Kondisi } \\
\text { Awal }\end{array}$} & \multicolumn{2}{|c|}{ Siklus I } & \multicolumn{2}{|c|}{ Siklus II } \\
\hline $\mathrm{O}$ & & $\mathrm{F}$ & $\%$ & $\mathrm{~F}$ & $\%$ & $\mathrm{~F}$ & $\%$ \\
\hline 1 & Berkembang Sangat Baik & - & $0 \%$ & - & $0 \%$ & 1 & $33,3 \%$ \\
\hline 2 & Berkembang Sesuai Harapan & 1 & $33,3 \%$ & 1 & $33,3 \%$ & 2 & $66,6 \%$ \\
\hline 3 & Mulai Berkembang & 1 & $33,3 \%$ & 2 & $66,6 \%$ & - & $0 \%$ \\
\hline 4 & Belum Berkembang & 1 & $33,3 \%$ & - & $0 \%$ & - & $0 \%$ \\
\hline & Jumlah & 3 & $100 \%$ & 3 & $100 \%$ & 3 & $100 \%$ \\
\hline
\end{tabular}


Grafik 4

Hasil Rekapitulasi Keberhasilan Peserta Didik

Dari Kondisi Awal, Siklus I, dan Siklus II

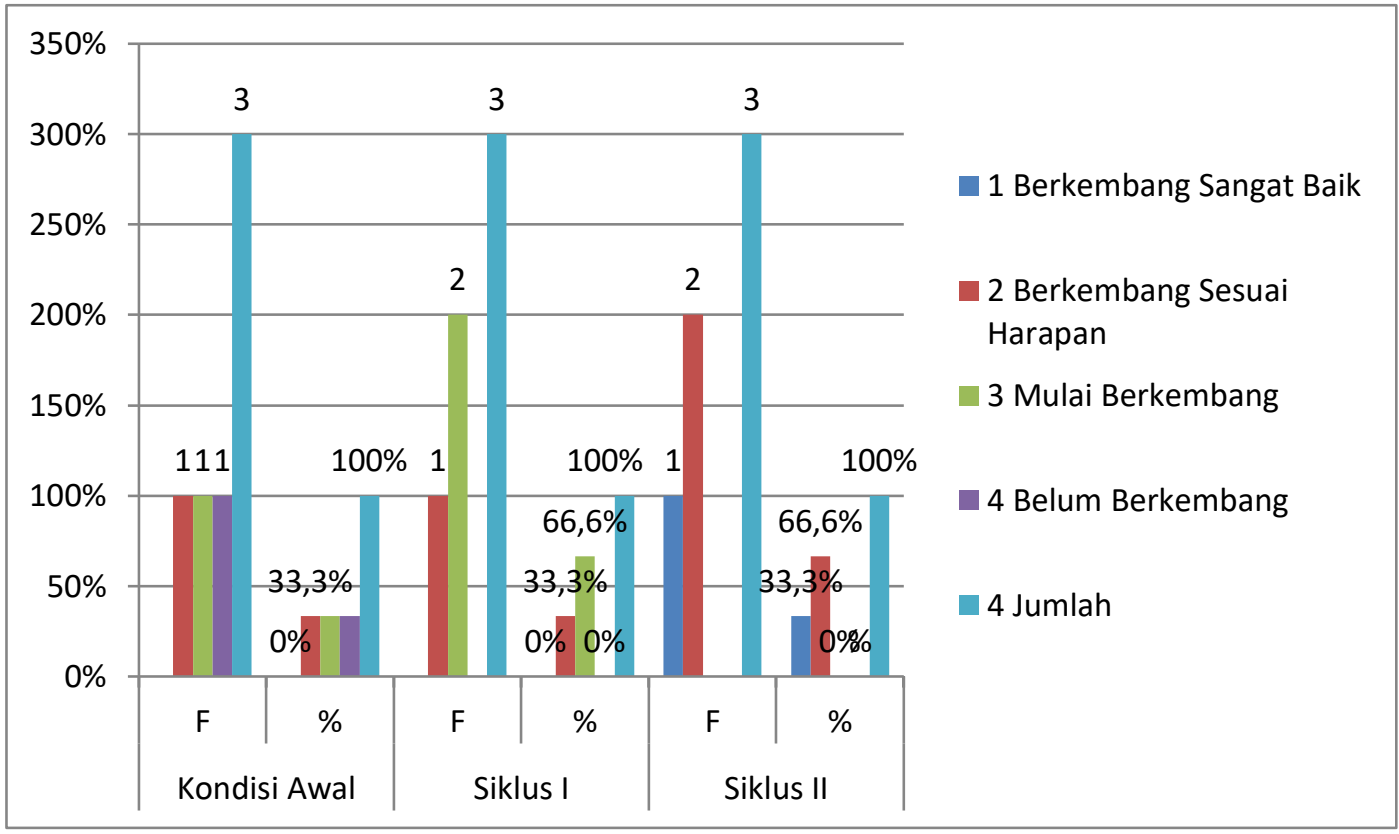

Berdasarkan hasil rekapitulasi keberhasilan anak dari mulai kondisi awal, siklus I dan siklus II menunjukkan bahwa perbaikan yang dilakukan pada siklus II Upaya Meningkatkan Kedisiplinan Peserta Didik Melalui Penguatan Pendidikan Karakter (PPK) di SMA Negeri 9 Yogyakarta mengalami peningkatan dan kekurangan yang terjadi pada siklus sebelumnya sudah dapat teratasi dengan baik upaya meningkatkan kedisiplinan peserta didik melalui penguatan pendidikan karakter (PPK) di SMA Negeri 9 Yogyakarta peserta didik menjadi lebih baik dan berkembang secara optimal. Oleh karena itu perbaikan pembelajaran untuk meningkatkan upaya meningkatkan kedisiplinan peserta didik melalui penguatan pendidikan karakter (PPK) di SMA Negeri 9 Yogyakarta sudah cukup dihentikan pada siklus II dan tidak perlu dilanjutkan lagi pada siklus selanjutnya.

\section{SIMPULAN DAN REKOMENDASI}

\section{Simpulan}

Berdasarkan hasil penelitian dan pembahasan yang dilakukan, dapat disimpulkan bahwa kegiatan best practice upaya meningkatkan kedisiplinan peserta didik melalui penguatan pendidikan karakter (PPK) di SMA Negeri 9 Yogyakarta dibuktikan dengan adanya peningkatan rata-rata kedisiplinan peserta didik berkembang secara optimal yaitu dari kelas $\mathrm{X}, \mathrm{XI}$ dan XII. Dari kondisi awal masih rendah atau belum berkembang secara optimal yaitu dari keseluruhan kelas X, XI dan XII. Semua kelas X belum berkembang, kelas XI mulai berkembang dan kelas XII berkembang sesuai harapan, pada Siklus I mengalami peningkatan dibandingkan dengan kondisi awal sebelum tindakan perbaikan yaitu dengan kriteria mulai berkembang tadinya hanya kelas XI berubah menjadi kelas X dan XI dan kelas XII berkembang sesuai harapan, pada tindakan siklus II mengalami peningkatan dibandingkan 
siklus I, pada siklus I semua kelas X dan XI mulai berkembang dan kelas XII berkembang sesuai harapan berubah menjadi kelas X berkembang sesuai harapan dan kelas XI dan XII berkembang sangat Baik, sedangkan untuk kriteria penilain mulai berkembang dan belum berkembang sudah tidak ada lagi.

\section{Rekomendasi}

Berdasarkan kesimpulan di atas, beberapa rekomendasi yang dapat diberikan adalah sebagai berikut:

1. Meningkatkan kedisiplinan peserta didik melalui nilai-nilai ketaatan, kepatuhan, keteraturan, dan ketertiban yang lebih baik lagi;

2. Meningkatkan perilaku peserta didik yang didasarkan pada upaya menjadikan dirinya sebagai orang yang selalu dapat dipercaya dalam perkataan, tindakan, dan pekerjaan, memiliki komitmen dan kesetiaan pada nilai-nilai kemanusiaan dan moral (integritas moral).

\section{Daftar Pustaka}

Depdiknas. 2002 Pedoman Pembangunan Karakter bangsa di Sekolah Lanjutan Tingkat Atas, Direktorat pendidikan Dasar dan menengah ,Jakarta.

Depdiknas. 2003. UU RI No. 20 Tabun 2003 tentang Sistem Pendidikan Nasional. Jakarta: Depdiknas.

Kemendiknas. 2011. Panduan Pelaksanaan Pendidikan Karakter. Badan Penelitian dan Pengembangan Pusat Kurikulum dan Perbukuan. Jakarta.

Koesoema, D.A. 2007. Pendidikan Karakter: Strategi Mendidik Anak di Zaman Global. Grasindo. Jakarta.

Marzuki. 2013. Revitalisasi Pendidikan Agama di Sekolah dalam Pembangunan Karakter Bangsa di Masa Depan. Jurnal Pendidikan Karakter. 3 (1): 64-76.

Pemerintah Republik Indonesia. 2010. Kebijakan Nasional Pembangunan Karakter Bangsa Tahun 2010-2025. Jakarta.

Sari, N.K. 2013. Pendidikan dan Pembinaan Karakter Bangsa. http://nuriithaa.blogspot.com/2013/04/pendidikan-dan-pembinaan-karakter-bangsa. html.

Arikunto, S. 1996 Prosedur Penelitian Suatu Pendekatan Praktek .Jakarta . Rineka Cipta

Arikunto, S. 2002. Penelitian Tindakan Kelas, Makalah pada Pendidikan dan pelatihan ( TOT) Pengembangan Profesi bagi Jabatan Jabatan Fungsional Guru, $\quad 11$ - 20 Juli 2002 di Balai Penataran Guru ( BPG) Semarang.

Suyatno. 2010. Peran Pendidikan Sebagai Modal Utama Membangun Karakter Bangsa. Makalah disampaikan pada Saresehan Nasional 'Pembangunan Pendidikan Budaya dan Karakter Bangsa'. Kopertis Wilayah III. Jakarta. 12 Januari 2010.

Widayanto. 2013. Mengimplementasikan Pendidikan Karakter Bangsa di Lingkungan Sekolah dan Masyarakat. Widyaiswara Madya BDK Surabaya. http:// bdsurabaya.kemenag.go.id/file/dokumen/PBKB1.pdf.

Wiriaatmadja, Rochiati, Prof.Dr. 2005 . Metode Penelitian Tindakan Kelas . PPS UPI dan Remaja Rosdakarya; Bandung 